\title{
Epigenetics of Neurodevelopmental Disorders Comes of Age with Roles in Clinical and Educational Applications
}

\author{
Takeo Kubota \\ Faculty of Child Studies, Seitoku University, Chiba 271-8555, Japan; takeokubota27@gmail.com
}

Received: 5 September 2018; Accepted: 8 September 2018; Published: 12 September 2018

Epigenetics is a gene regulation mechanism that does not depend on genomic DNA sequences, but depends instead on chemical modifications of DNA and histone proteins. The failure of epigenetic mechanisms is known to cause congenital neurodevelopmental disorders (NDs), which include genomic imprinting disorders (e.g., Prader-Willi and Angelman syndrome) [1], X-chromosome inactivation disorders (e.g., ring $X$ Turner syndrome) [2], and epigenetic regulation-associated molecular disorders (e.g., Rett syndrome and Kleefstra syndrome) [3,4]. These indicate that the epigenetic system is essential for normal birth and development.

It has been recently reported that the number of children with NDs has increased in several countries, such as the US, Korea, and Japan, in which environmental factors, rather than genetic factors, are thought to be involved in this increase. Since epigenetic modifications in DNA are more vulnerable than DNA sequences to environmental stressors such as malnutrition, environmental chemicals, and mental stress, especially during the early period of life, one can speculate that current socioenvironmental factors cause acquired NDs via epigenetic alterations in the brain [5-7].

The epigenome has a reversible property since it is based on removable residues on genomic DNA. Thus, environmentally induced epigenomic alterations can be potentially restored. In fact, some medicines for psychiatric and epileptic disorders are known to restore an altered epigenome, resulting in the correction of gene expression [8-11]. Therefore, epigenomic-based preemptive medicine that consists of early detection using epigenomic signatures and early interventions that take advantage of the use of epigenomic reversibility are expected.

Under these circumstances, we are pleased to have this opportunity to compile a special issue entitled "Epigenetics of neurodevelopmental disorders" for the International Journal of Molecular Sciences. As a Guest Editor, I would like to thank Prof. Dr. Maurizio Battino, an Editor-in-Chief of this journal, for this great opportunity.

I am very proud of the papers contributed to this section that consists of eight review articles by top-level epigenetic researchers in the world. Through this issue, readers will learn current epigenetic understanding of brain function, congenital NDs, and acquired NDs [12-19]. More precisely, Cariaga-Martínez et al. extensively described epigenetic properties in embryonic stem cells and throughout early development phases [12]. Ma et al. revealed a microRNA involved in the pathogenesis of neonatal hypoxic-ischemic encephalopathy and its therapeutic use with complementary oligonucleotides of this microRNA [13]. Hernandez et al. reported an epigenetic mechanism that regulates thyroid hormone in the brain [14]. Kim et al. and Lepri et al. summarized NDs caused by mutations in histone lysine methylation-related genes and Kabuki syndrome, a representative congenital neurodevelopmental disorder caused by mutations in the lysine methyltransferase 2D gene $[15,16]$. Zapata-Martín Del Campo et al. demonstrated subcellular mechanisms of neuropsychiatric and cardiometabolic disorders induced by environmental exposures in the early stages of life and the underlying neuroendocrine mechanisms $[17,18]$. Hoffmann et al. 
discussed the phenotypic contributions of epigenomic responses to early life adversities to major depressive disorders and schizophrenia [19].

I hope this collection of papers will help readers to gain a better understanding of what has been done and what is yet to be done in the field of preemptive medicine of NDs, and how this subject is intimately associated with nursing and education in the early stages of life.

Conflicts of Interest: The author declares no conflict of interest.

\section{References}

1. Kubota, T.; Das, S.; Christian, S.L.; Baylin, S.B.; Herman, J.G.; Ledbetter, D.H. Methylation-specific PCR simplifies imprinting analysis. Nat. Genet. 1997, 16, 16-17. [CrossRef] [PubMed]

2. Kubota, T.; Wakui, K.; Nakamura, T.; Ohashi, H.; Watanabe, Y.; Yoshino, M.; Kida, T.; Okamoto, N.; Matsumura, M.; Muroya, K.; et al. The proportion of cells with functional X disomy is associated with the severity of mental retardation in mosaic ring X Turner syndrome females. Cytogenet. Genome Res. 2002, 99, 276-284. [CrossRef] [PubMed]

3. Amir, R.E.; Van den Veyver, I.B.; Wan, M.; Tran, C.Q.; Francke, U.; Zoghbi, H.Y. Rett syndrome is caused by mutations in X-linked MECP2, encoding methyl-CpG-binding protein 2. Nat. Genet. 1999, 23, 185-188. [CrossRef] [PubMed]

4. Kleefstra, T.; Kramer, J.M.; Neveling, K.; Willemsen, M.H.; Koemans, T.S.; Vissers, L.E.; Wissink-Lindhout, W.; Fenckova, M.; van den Akker, W.M.; Kasri, N.N.; et al. Disruption of an EHMT1-associated chromatin-modification module causes intellectual disability. Am. J. Hum. Genet. 2012, 91, 73-82. [CrossRef] [PubMed]

5. Weaver, I.C.; Cervoni, N.; Champagne, F.A.; D'Alessio, A.C.; Sharma, S.; Seckl, J.R.; Dymov, S.; Szyf, M.; Meaney, M.J. Epigenetic programming by maternal behavior. Nat. Neurosci. 2014, 9, 847-854. [CrossRef] [PubMed]

6. McGowan, P.O.; Sasaki, A.; D’Alessio, A.C.; Dymov, S.; Labonté, B.; Szyf, M.; Turecki, G.; Meaney, M.J. Epigenetic regulation of the glucocorticoid receptor in human brain associates with childhood abuse. Nat. Neurosci. 2009, 12, 342-348. [CrossRef] [PubMed]

7. Murgatroyd, C.; Patchev, A.V.; Wu, Y.; Micale, V.; Bockmühl, Y.; Fischer, D.; Holsboer, F.; Wotjak, C.T.; Almeida, O.F.; Spengler, D. Dynamic DNA methylation programs persistent adverse effects of early-life stress. Nat. Neurosci. 2009, 12, 1559-1566. [CrossRef] [PubMed]

8. Tsankova, N.M.; Berton, O.; Renthal, W.; Kumar, A.; Neve, R.L.; Nestler, E.J. Sustained hippocampal chromatin regulation in a mouse model of depression and antidepressant action. Nat. Neurosci. 2006, 9, 519-525. [CrossRef] [PubMed]

9. Jessberger, S.; Nakashima, K.; Clemenson, G.D.; Mejia, E., Jr;; Mathews, E.; Ure, K.; Ogawa, S.; Sinton, C.M.; Gage, F.H.; Hsieh, J. Epigenetic modulation of seizure-induced neurogenesis and cognitive decline. J. Neurosci. 2007, 27, 5967-5975. [CrossRef] [PubMed]

10. Dong, E.; Nelson, M.; Grayson, D.R.; Costa, E.; Guidotti, A. Clozapine and sulpiride but not haloperidol or olanzapine activate brain DNA demethylation. Proc. Natl. Acad. Sci. USA 2008, 105, 13614-13619. [CrossRef] [PubMed]

11. Wang, Q.; Xu, X.; Li, J.; Liu, J.; Gu, H.; Zhang, R.; Chen, J.; Kuang, Y.; Fei, J.; Jiang, C.; et al. Lithium, an anti-psychotic drug.; greatly enhances the generation of induced pluripotent stem cells. Cell Res. 2011, 21, 1424-1435. [CrossRef] [PubMed]

12. Cariaga-Martínez, A.E.; Gutiérrez, K.J.; Alelú-Paz, R. The Vast Complexity of the Epigenetic Landscape during Neurodevelopment: An Open Frame to Understanding Brain Function. Int. J. Mol. Sci. 2018, 19, 1333. [CrossRef] [PubMed]

13. Ma, Q.; Dasgupta, C.; Li, Y.; Huang, L.; Zhang, L. MicroRNA-210 Suppresses Junction Proteins and Disrupts Blood-Brain Barrier Integrity in Neonatal Rat Hypoxic-Ischemic Brain Injury. Int. J. Mol. Sci. 2017, 18, 1356. [CrossRef] [PubMed]

14. Hernandez, A.; Stohn, J.P. The Type 3 Deiodinase: Epigenetic Control of Brain Thyroid Hormone Action and Neurological Function. Int. J. Mol. Sci. 2018, 19, 1804. [CrossRef] [PubMed] 
15. Kim, J.-H.; Lee, J.H.; Lee, I.-S.; Lee, S.B.; Cho, K.S. Histone Lysine Methylation and Neurodevelopmental Disorders. Int. J. Mol. Sci. 2017, 18, 1404. [CrossRef] [PubMed]

16. Lepri, F.R.; Cocciadiferro, D.; Augello, B.; Alfieri, P.; Pes, V.; Vancini, A.; Caciolo, C.; Squeo, G.M.; Malerba, N.; Adipietro, I.; et al. Clinical and Neurobehavioral Features of Three Novel Kabuki Syndrome Patients with Mosaic KMT2D Mutations and a Review of Literature. Int. J. Mol. Sci. 2018, 19, 82. [CrossRef] [PubMed]

17. Zapata-Martín del Campo, C.M.; Martínez-Rosas, M.; Guarner-Lans, V. Epigenetics of Subcellular Structure Functioning in the Origin of Risk or Resilience to Comorbidity of Neuropsychiatric and Cardiometabolic Disorders. Int. J. Mol. Sci. 2018, 19, 1456. [CrossRef] [PubMed]

18. Zapata-Martín del Campo, C.M.; Martínez-Rosas, M.; Guarner-Lans, V. Epigenetic Programming of Synthesis, Release, and/or Receptor Expression of Common Mediators Participating in the Risk/Resilience for Comorbid Stress-Related Disorders and Coronary Artery Disease. Int. J. Mol. Sci. 2018, 19, 1224. [CrossRef] [PubMed]

19. Hoffmann, A.; Sportelli, V.; Ziller, M.; Spengler, D. Epigenomics of Major Depressive Disorders and Schizophrenia: Early Life Decides. Int. J. Mol. Sci. 2017, 18, 1711. [CrossRef]

(C) 2018 by the author. Licensee MDPI, Basel, Switzerland. This article is an open access article distributed under the terms and conditions of the Creative Commons Attribution (CC BY) license (http:/ / creativecommons.org/licenses/by/4.0/). 